\title{
Localising the nitrogen imprint of the Paris food supply: the potential of organic farming and changes in human diet
}

\author{
G. Billen ${ }^{1}$, J. Garnier ${ }^{1}$, V. Thieu ${ }^{2}$, M. Silvestre ${ }^{1}$, S. Barles ${ }^{3}$, and P. Chatzimpiros ${ }^{4}$ \\ ${ }^{1}$ UMR Sisyphe, UPMC/CNRS, Paris, France \\ ${ }^{2}$ IES, IRC, Ispra, Italy \\ ${ }^{3}$ Geo-cité, Université Paris 1-Sorbonne, Paris, France \\ ${ }^{4}$ LEESU/Génie Urbain, UPEMLV - cité Descartes, 77454 Marne-la-Vallée, France
}

Correspondence to: G. Billen (gilles.billen@upmc.fr)

Received: 14 July 2011 - Published in Biogeosciences Discuss.: 10 November 2011

Revised: 13 January 2012 - Accepted: 18 January 2012 - Published: 31 January 2012

\begin{abstract}
The Seine watershed has long been the foodsupplying hinterland of Paris, providing most of the animal and vegetal protein consumed in the city. Nowadays, the shift from manure-based to synthetic nitrogen fertilisation, has made possible a strong land specialisation of agriculture in the Seine watershed: it still provides most of the cereal consumed by the Paris agglomeration, but exports $80 \%$ of its huge cereal production. On the other hand the meat and milk supply originates mainly from regions in the North and West of France, specialised in animal farming and importing about $30 \%$ of their feed from South America. As it works today, this system is responsible for a severe nitrate contamination of surface and groundwater resources. Herein two scenarios of re-localising Paris's food supply are explored, based on organic farming and local provision of animal feed. We show that for the Seine watershed it is technically possible to design an agricultural system able to provide all the plant- and animal-based food required by the population, to deliver sub-root water meeting the drinking water standards and still to export a significant proportion of its production to areas less suitable for cereal cultivation. Decreasing the share of animal products in the human diet has a strong impact on the nitrogen imprint of urban food supply.
\end{abstract}

\section{Introduction}

Food supply is a major factor in shaping cities (Steele, 2010) and determining their relationships with surrounding (close or distant) rural territories. The agricultural development in the city hinterland as well as the construction of large transport infrastructures has been largely dictated by the requirements of urban food markets (Keene, 2011; Charruadas, 2011; Billen et al., 2011). Because cities consume most of the final products of agriculture and dictate its specialisation and location, urbanisation is a major driver of the human perturbation of the nitrogen cycle (Svirejeva-Hopkins and Reis, 2011). As shown by several authors, the anthropogenic introduction into the biosphere of reactive nitrogen, which subsequently cascades through a number of environmental compartments until it is finally denitrified back to the atmosphere, causing multiple harmful effects, is nowadays among the most severe environmental threats (Galloway et al., 2002; Sutton et al., 2011). Any attempt to eliminate or reduce the source of the nitrogen cascade should take into account the urban food supply issue.

There is presently a lively debate on the possibility of local sourcing of the urban food supply. Food-Miles, i.e. the total transport distance covered by foodstuffs from their production to their consumption sites, have been proposed as an indicator of sustainability of the human food system (Paxton, 1994; Smith et al., 2005). However, in an analysis of the US food supply chain, Weber and Matthews (2008) showed that foodstuff transportation is only a minor term in its total carbon imprint and that changes in agricultural practices or in the composition of human diet would have a much more pronounced effect on greenhouse gas emission than reduction of the food transport distance. They conclude that the issue of localisation of the food supply is not a question of climate impact optimisation but is conditioned by the political will to support local agricultural communities and to restore the link between cities and their rural hinterland. The latter concern is revealed by the recent and quite rapid development in the Western world of citizen organisations aiming to reconnect food production and urban consumption, as well as directly controlling the quality of products and the environmental impact of their production, through direct contracts between farmers and groups

Published by Copernicus Publications on behalf of the European Geosciences Union. 
of concerned consumers (Community Supported Agriculture in North America and the UK, www.localharvest.org; AMAP in France, www.reseau-amap.org; Gruppi di Acquisto Solidali in Italy, www.retegas.org; Teikei in Japan, etc.) (www.urgenci.net) (Watts et al., 2005).

As water is also a food, drinking water provision is another important aspect of the food supply. Because of their intensive use of fertilisers and pesticides, modern agricultural practices often lead to severe degradation of the quality of water produced by rural territories. A conflict therefore exists in the allocation of land areas for either drinking water or food production. Some large cities, such as New York in the US, made the choice of reserving certain nearby lands for clean drinking water production, excluding agricultural activities (Swaney et al., 2012). Others, such as Athens in Greece (Stergiouli et al., 2012) and Barcelona in Spain (Tello et al., 2011), extend their water supply areas over a very long distance, annexing the water resources of other watersheds. In a few instances, such as in Munich (http://www.partagedeseaux.info/article226.html), a deliberate policy was implemented to reconcile water and food production in the surrounding hinterland, with organic agriculture being promoted through the establishment of a strong public urban market demand.

The case of the huge Paris agglomeration offers an interesting example to study the potentiality of changes in the relationships between a large city and its food-supplying area, in particular in terms of its contribution to the nitrogen cascade. Previous studies (Billen et al., 2009, 2011) have traced back the geographical areas supplying food (measured as protein $\mathrm{N}$ content) to the Paris agglomeration during the last two centuries, a period when the city grew from 700000 inhabitants in 1786 to 11500000 at the present time: its per capita $\mathrm{N}$ consumption rose from 5.4 to $7.7 \mathrm{~kg} \mathrm{~N} \mathrm{cap}^{-1} \mathrm{yr}^{-1}$, and the share of animal products in the diet increased from 39 to $65 \%$ of total protein consumption. Part of the consumption increase is due to higher intake, while another part is the result of higher waste generation all along the food chain (currently estimated to about $30 \%$ of the total in Europe, Gustavsson et al., 2011). Surprisingly, these major changes in the city's food demand were not accompanied by a considerable extension of the mean food supply distance, but rather by deep reorganisation, specialisation and opening of agriculture in the hinterland. On the other hand, the Seine watershed still represents the only source of drinking water for Paris, with two-thirds coming from surface water and one-third from groundwater resources, both threatened by increasing nitrate contamination (Billen et al., 2007; Ledoux et al., 2007). Previous studies have also shown that only radical changes in agricultural practices would be able to durably reduce nitrate pollution of ground and surface water in the Seine watershed (Thieu et al., 2010a, b; Lancelot et al., 2011).
This paper pursues the analysis of the environmental imprint of Paris's food consumption on the biogeochemical functioning of its rural hinterland and attempts to bring out the relations between urban demand for foodstuffs, nitrogen cycling in agricultural systems, and nitrate contamination of water resources. We then explore the potentialities of radically changing both the agricultural practices and the urban diet patterns for reducing the environmental imprint of urban food consumption.

\section{Approach and methods}

The approach applied herein takes inspiration from the concepts and methods of territorial ecology as defined by Barles (2010). Starting from the urban demand, we first delimited the territory supplying food to the Paris agglomeration, then analysed the fluxes of material involved in its production and supply. Based on the results of this analysis, alternative scenarios able to fulfil the same functions while meeting additional constraints are imagined.

To define the historical and current food supply areas of the Paris agglomeration and to analyse the functioning of their agricultural system, a combination of agricultural and transport statistics were used. In particular for the present period, we made use of the national agricultural statistics, available at the département level (Agreste, Ministry of Agriculture, www.agreste.agriculture.gouv.fr/). The French départements are territorial and administrative divisions of about $7000 \mathrm{~km}^{2}$, except for Paris which is a much smaller département in itself. For estimating the origin of agricultural goods consumed in Paris, the SitraM database on commodity transport between French départements (French Ministry of Environment, www. statistiques.developpement-durable.gouv.fr/) and the FAO statistics on production and international trade of food products (http://faostat.fao.org/) were compiled (Billen et al., 2011). All crop and animal product quantities, originally provided in tons, were converted to their nitrogen weight equivalent using the $\mathrm{N}$ content figures $(1.8 \% \mathrm{~N}$ for cereals, $3.4 \% \mathrm{~N}$ for meat, $0.5 \%$ for milk and $0.1-0.4 \%$ for most fruits and vegetables) presented in Billen et al. (2009). The relationship between crop production (in terms of $\mathrm{N}$ content) and total $\mathrm{N}$ fertilisation of arable land (manure, synthetic fertilisers, symbiotic $\mathrm{N}$ fixation and atmospheric deposition) was established at the département scale. Data on the use of synthetic fertilisers by département were provided by Unifa (2008). Symbiotic N fixation was estimated from the yield of each legume crop, considering that underground and unharvested parts together represent $40 \%$ of the yield. The yield-fertilisation relationship was then used to calculate agricultural production in the different scenarios explored (see below) and to assess the environmental losses of nitrogen by the agro-systems, considering that all $\mathrm{N}$ used in 


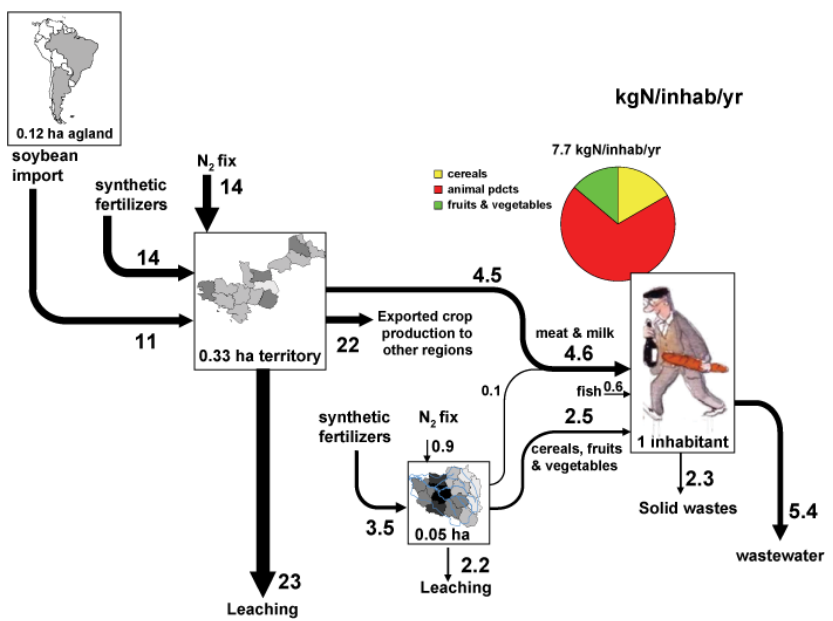

Fig. 1. Schematic representation of the nitrogen imprint of the food supply of one Paris inhabitant. Nitrogen fluxes involved are expressed in $\mathrm{kg} \mathrm{N}$ inhab $^{-1} \mathrm{yr}^{-1}$. The figures are derived from the description established in Billen et al. (2011).

food production that is not in the crop product is lost to the environment.

\section{The current nitrogen imprint of Paris food consumption}

Until the middle of the 20th century, Paris was still mainly supplied by an area roughly corresponding to a $150-\mathrm{km}$ circle around the city, including most of the Seine watershed. Although a certain degree of agricultural specialisation was already present within this area, the agricultural system was fundamentally based on a close relation between cereal cultivation and livestock farming, the latter producing the organic fertilisers required by the former. The increase of grain yield during the 19th century mostly resulted from an improvement in animal feeding and manure management, owing to the replacement of the triennial fallow by a $\mathrm{N}_{2}$-fixing legume fodder crop, which provided a considerable increase in livestock density (Billen et al., 2009, 2011).

The 20th century agrarian revolution, following the generalisation of the use of synthetic $\mathrm{N}$ fertilisers, led to pronounced spatial segregation between the regions of the central Paris basin - specialised in cereal cultivation at the expense of livestock farming - and the more peripheral regions, which specialised in cattle rearing and imported a large share of the feed from other regions, countries or continents. Today, Paris's main food-supplying area is composed of three areas with quite different biogeochemical functioning (Billen et al., 2011): i. The directly surrounding area corresponding to the Seine watershed is now mainly devoted to intensive cereal farming and provides most of the vegetal proteins consumed in Paris. It exports $82 \%$ of its production.

ii. The area made up of Brittany, Normandy and NordPas-de-Calais produces the largest fraction of the animal proteins consumed in Paris, but depends on massive imports of feed from other regions.

iii. Among the imports of vegetal proteins required for feeding the livestock of the latter territory, soybean and oilcake meals from Brazil and Argentina are the most significant: the size of the agricultural surfaces involved is similar to that of the two other territories.

These three areas together contribute $70 \%$ of the needs of Paris consumption. The remaining $30 \%$ is supplied half by other French départements and half by foreign countries.

From these data, the environmental imprint of the Paris food supply can be approximately represented in terms of (i) the land area required and (ii) per capita nitrogen fluxes involved, exactly as is currently done for wastewater domestic effluents (Fig. 1). To satisfy the needs in vegetal products of one Paris inhabitant, only 0.05 ha of the territory of the Seine watershed is required, but 0.33 ha of territory in polycultureanimal farming areas such as those of Brittany, Normandy and Nord-Pas-de-Calais are required to satisfy the needs in meat and milk of the same person (although some surplus crop production in this area is available to supply other regions); in addition, an area of about 0.12 ha in South America is required to supplement the feed of the livestock in the latter region. This indicates that by far the largest territorial area required to feed Paris is for producing animal products. This is not surprising as for the whole of Europe, $83 \%$ of crop production is destined to feeding livestock (Sutton et al., 2011).

To estimate the losses occurring through leaching and volatilisation from agricultural soils in the two French supply areas, we calculated the difference between total fertilisation and crop production of agricultural land (both expressed in $\mathrm{N}$ content) at the département scale. The relationship between crop yield and total fertilisation follows an asymptotic curve (Fig. 2a), with the surplus (i.e. the difference between fertilisation and yield) increasing regularly with increasing fertilisation (Fig. 2b). The surplus is generally lower in the cereal crop regions of the centre of the Paris basin than in the intensive livestock farming areas of the West of France. If the surplus is assumed to be entirely diluted in the infiltrating water depth (as a mean $300 \mathrm{~mm} \mathrm{yr}^{-1}$ for the areas described herein), the corresponding theoretical sub-root nitrate concentration in water produced by agland surfaces can be calculated. In most départements, the value is far above the drinking water standard of $11 \mathrm{mg} \mathrm{Nl}^{-1}\left(50 \mathrm{mg} \mathrm{NO}_{3} \mathrm{l}^{-1}\right)$. In these regions, agland occupies about half the total area. 

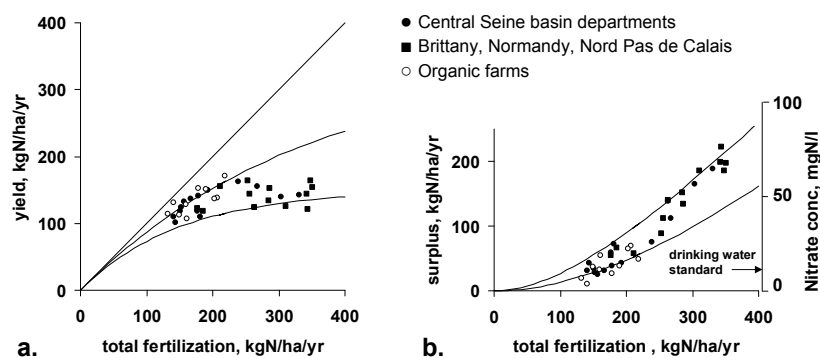

Fig. 2. (a) Relationship between crop yield and total fertilisation (both expressed in $\mathrm{kg} \mathrm{Nha}^{-1} \mathrm{yr}^{-1}$ ) of agricultural land of the different French départements mainly involved in the Paris food supply. The following mathematical function has been fitted to give the upper and lower bounds of the data points: $y$ ield $=Y \max \cdot(1-\exp (-$ Fert/Ymax $))$, with Ymax $=350-150 \mathrm{~kg} \mathrm{Nha}^{-1} \mathrm{yr}^{-1}$. (b) Agricultural surplus (total fertilisation minus crop yield) plotted against fertilisation. The corresponding theoretical sub-root water concentration, calculated assuming a mean runoff depth of $300 \mathrm{~mm} \mathrm{yr}^{-1}$, is also indicated (right scale). The data available for a number of organic farms in the Seine watershed (unpublished results) are also shown for comparison (open symbols).

For the two French agricultural areas supplying food to Paris, the estimated environmental losses of nitrogen are estimated at $25 \mathrm{~kg} \mathrm{~N}$ capita ${ }^{-1} \mathrm{yr}^{-1}$, i.e. five times the load discharged as urban wastewater by one inhabitant. The largest part $(92 \%)$ of these losses occurs in the livestock farming supply territory. Admittedly, because some surplus vegetal production of this territory is exported to other regions, a fraction of the losses occurring there should be ascribed to the population of these regions.

\section{A local and organic farming scenario for the Seine watershed}

Thieu et al. (2010b) have shown that organic agriculture, if generalised to the entire agriculture area of the Seine watershed, has the potential to restore nitrogen contamination to a level below the ecological water resources standards. In order to explore the potential of reducing the nitrogen imprint of the Paris food supply, we constructed a hypothetical scenario based on the following constraints:

The organic and local scenario (OrgLoc) first requires that most of the food supply be produced within the limits of the Seine watershed, Paris's traditional food-producing hinterland. This necessarily implies restoring livestock farming within the area. The scenario assumes, however, that this livestock be reared with only local feed: no import of proteins from outside the Seine watershed limits would be allowed. To calculate the feed consumed by this livestock, we used a nitrogen conversion ratio of $17 \%$, the current average value calculated for the Brittany-Normandy-NordPas-de-Calais regions.

The scenario also assumes organic agricultural practices, implying no use of synthetic fertilisers, all the fertilisation of arable land being ensured through symbiotic nitrogen fixation and manure application. Our calculations assume that the currently observed relationship between yield and total fertilisation shown in Fig. 2 also holds for organic practises. This assumption implies that at a similar fertilisation rate, whether the fertilisation is organic or mineral, the yields are identical. In other words, the often observed lower yields of organic vs. conventional farming are the results of lower fertilisation rather any other difference. The upper relationship illustrated in Fig. 2

$$
\text { Yield }=\text { Ymax }(1-\exp (- \text { fertilization/Ymax }))
$$

(with $\mathrm{Ymax}=350 \mathrm{~kg} \mathrm{~N} \mathrm{ha}^{-1} \mathrm{yr}^{-1}$ ) is used in the calculation, once the total fertilisation (manure, legume $\mathrm{N}_{2}$ fixation and atmospheric deposition) is known, to calculate both the yield of arable land and the nitrogen surplus defined as the difference between fertilisation and yield. In the construction of the OrgLoc scenario, the first step is to assess the size of the livestock required to sustain the needs of the local population. The current area of permanent grassland in the Seine watershed is maintained unchanged. The size of the nitrogen-fixing arable land (temporary grassland involved in crop succession and legume fodder crops) is adjusted so as to meet the feed requirements of livestock with (i) the production of the permanent grassland, (ii) $70 \%$ of the production of nitrogen-fixing crops (30\% is considered to be used as green manure, thus not available for livestock feeding) and (iii) an adjustable fraction of the production of non-legume crops. The total fertilisation of arable land can thus be calculated as well as the yield and the nitrogen surplus of arable land. The theoretical sub-root nitrate concentration below arable land is evaluated by dividing the surplus by the infiltrated water depth. Finally, the calculated production of non-fixing cropland which has not been allocated to human or animal feeding is considered available for export. Table 1 and Fig. 3 summarise the calculations and compare the results with the current situation.

These calculations show that it is quite possible to conceive a scenario of organic farming locally meeting the quantitative food requirements of the current population of the Paris agglomeration and of the other cities of the Seine watershed, totalling 16.9 million inhabitants, provided that the livestock density is increased from the current value of $18 \mathrm{LU} \mathrm{km}^{-2}$ to $50 \mathrm{LU} \mathrm{km}^{-2}$. The basin should still be able to export about $1630 \mathrm{~kg} \mathrm{~N} \mathrm{~km}^{-2} \mathrm{yr}^{-1}$. This should be compared to the current cereal export of $4820 \mathrm{~kg} \mathrm{~N} \mathrm{~km}^{-2} \mathrm{yr}^{-1}$, an amount reduced to a net protein export of $800 \mathrm{~kg} \mathrm{~N} \mathrm{~km}^{-2} \mathrm{yr}^{-1}$ if the import of feed and animal products, as well as the vegetal proteins required for the production of the latter, are deducted (Fig. 3a). In this OrgLoc scenario, however, the nitrogen surplus, although lower than 
Table 1. Nitrogen budget of the agricultural system of the Seine watershed for the current situation (2006) and the organic and local (OrgLoc) and organic, local and demitarian (OrgLocDem) scenarios. The 2006 situation is primarily based on agricultural statistics (Agreste, 2007), with a few items calculated as explained in the text and summarised in the "remarks" column. The OrgLoc and OrgLocDem scenarios are calculated starting from the current situation and reallocating land use and livestock numbers in order to meet the following constraints: no use of synthetic fertilisers (organic fertilisation only), no import of feed (self-sufficiency in animal nutrition), no import of animal products (self-sufficiency in supplying animal products for local human consumption). Cereal production is calculated from the yield/fertilisation relationship observed for the Seine basin départements in the current situation. Cereal production in excess of livestock and human requirements is exported. Nitrate concentration in infiltrating sub-root water is estimated from the difference between fertilisation and yield in arable land, taking into account an infiltration rate of $300 \mathrm{~mm} \mathrm{yr}^{-1}$.

\begin{tabular}{|c|c|c|c|c|c|c|}
\hline & & 2006 & & OrgLoc & OrgLocDem & \\
\hline \multicolumn{7}{|l|}{ Main characteristics of the territory } \\
\hline total area & $\mathrm{km}^{2}$ & 92381 & Agreste (2007) (all déptmts) & 92381 & 92381 & unchanged \\
\hline agricultural area & 1000 ha & 5119 & Agreste (2007) & 5119 & 5119 & unchanged \\
\hline population density & hab km ${ }^{-2}$ & 183 & INSEE (2007) & 183 & 183 & unchanged \\
\hline per capita protein consumption & 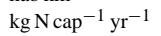 & 7 & FAOstat (2012) & 7 & 7 & unchanged \\
\hline$\%$ animal protein in diet & $\%$ & 65 & FAOstat (2012) & 65 & 40 & $\begin{array}{l}\text { unchanged for OrgLoc, reduced to } 40 \% \\
\text { for OrgLocDem }\end{array}$ \\
\hline \multicolumn{7}{|l|}{ Livestock farming } \\
\hline livestock density & $\mathrm{LU} \mathrm{km}^{-2}$ & 18 & Agreste (2007) & 49 & 30 & adjusted to meet population requirements \\
\hline meat and milk production & kton $\mathrm{N} \mathrm{yr}^{-1}$ & 15 & Agreste (2007) & 77 & 48 & assuming yield of $17 \%$ (mean value for France) \\
\hline manure production & kton $\mathrm{Nyr}^{-1}$ & 138 & $85 \mathrm{~kg} \mathrm{~N} \mathrm{LU}^{-1} \mathrm{yr}^{-1}$ & 387 & 238 & $85 \mathrm{~kg} \mathrm{~N} \mathrm{LU}^{-1} \mathrm{yr}^{-1}$ \\
\hline feed consumption & kton $\mathrm{Nyr}^{-1}$ & 153 & production + manure & 464 & 286 & production + manure \\
\hline \multicolumn{7}{|l|}{ Agriculture } \\
\hline \multicolumn{7}{|l|}{ permanent meadows } \\
\hline area & $1000 \mathrm{ha}$ & 800 & Agreste (2007) & 800 & 800 & same as current situation \\
\hline yield & $\mathrm{kg} \mathrm{Nha}^{-1} \mathrm{yr}^{-1}$ & 118 & Agreste (2007) & 118 & 118 & same as current situation \\
\hline production & kton $\mathrm{N} \mathrm{yr}^{-1}$ & 95 & Agreste (2007) & 95 & 95 & area $\times$ yield \\
\hline use as feed & $\%$ & 100 & & 100 & 100 & \\
\hline \multicolumn{7}{|l|}{$\mathbf{N}_{2}$ fixing crops + temporary meadows } \\
\hline area & $1000 \mathrm{ha}$ & 334 & Agreste (2007) & 2000 & 1150 & adjusted to meet livestock requirements \\
\hline yield & $\mathrm{kg} \mathrm{Nha}^{-1} \mathrm{yr}^{-1}$ & 171 & production/area & 150 & 150 & conservative estimate \\
\hline production & kton $\mathrm{Nyr}^{-1}$ & 57 & Agreste (2007) & 300 & 173 & area $\times$ yield \\
\hline $\mathrm{N}_{2}$ fixation & kton $\mathrm{Nyr}^{-1}$ & 80 & $1.4 \times$ production (aerial + root contrib.) & 420 & 242 & $1.4 \times$ production (aerial + root contribution) \\
\hline use as feed & $\%$ & 25 & Agreste (2007) & 70 & 70 & $\begin{array}{l}\text { conservative estimate, remaining part } \\
\text { used as green manure }\end{array}$ \\
\hline \multicolumn{7}{|l|}{ non fixing crops } \\
\hline area & 1000 ha & 3985 & Agreste (2007) & 2319 & 3169 & $\begin{array}{l}\text { agricultural area }-\left(\mathrm{N}_{2} \text { fixing crops }\right. \\
+ \text { temporary and permanent meadows })\end{array}$ \\
\hline average yield & $\mathrm{kgNha}^{-1} \mathrm{yr}^{-1}$ & 131 & production/area & 144 & 100 & $\begin{array}{l}\text { calculated from total fertilization, } \\
\text { using relationship of Fig. } 2\end{array}$ \\
\hline production & kton $\mathrm{N} \mathrm{yr}^{-1}$ & 523 & Agreste (2007) & 334 & 317 & yield $\times$ area \\
\hline use as feed & $\%$ & 7 & Agreste (2007) & 45 & 20 & $\begin{array}{l}\text { ajusted to meet livestock needs, } \\
\text { remaining used for human needs }\end{array}$ \\
\hline \multicolumn{7}{|l|}{ total arable land } \\
\hline arable area & $1000 \mathrm{ha}$ & 4319 & $\mathrm{~N}_{2}$ fixing and non fixing crops & 4319 & 4319 & $\mathrm{~N}_{2}$ fixing and non fixing crops \\
\hline total $\mathrm{N}_{2}$ fixation & $\mathrm{kg} \mathrm{Nha}^{-1} \mathrm{yr}^{-1}$ & 19 & $=\mathrm{N}_{2}$ fixation/arable area & 97 & 56 & $=\mathrm{N}_{2}$ fixation/arable area \\
\hline synthetic fertilizers & $\mathrm{kg} \mathrm{Nha}^{-1} \mathrm{yr}^{-1}$ & 161 & Unifa (2009) & 0 & 0 & no synthetic fertilizers \\
\hline manure & $\mathrm{kg} \mathrm{Nha}^{-1} \mathrm{yr}^{-1}$ & 32 & manure production/arable area & 87 & 54 & manure production/arable area \\
\hline atmospheric deposition & $\mathrm{kg} \mathrm{Nha}^{-1} \mathrm{yr}^{-1}$ & 12 & Ntot deposition, EMEP & 12 & 12 & Ntot deposition, EMEP \\
\hline total fertilization & $\mathrm{kg} \mathrm{Nha}^{-1} \mathrm{yr}^{-1}$ & 224 & 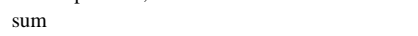 & 196 & 122 & sum \\
\hline total crop exportation & $\mathrm{kg} \mathrm{Nha}^{-1} \mathrm{yr}^{-1}$ & 124 & $\mathrm{~N}_{2}$ fixing used as feed and non fixing crops & 126 & 101 & $\mathrm{~N}_{2}$ fixing used as feed and non fixing crops \\
\hline \multicolumn{7}{|l|}{ System performance } \\
\hline \multicolumn{7}{|l|}{ coverage of livestock needs } \\
\hline local feed production & kton $\mathrm{Nyr}^{-1}$ & 145 & & 455 & 279 & \\
\hline local coverage of feed requirements & $\%$ & 95 & & 100 & 100 & \\
\hline $\begin{array}{l}\text { import of feed } \\
\text { fcoverage population needs }\end{array}$ & kton $\mathrm{N} \mathrm{yr}^{-1}$ & 8 & & 0 & 0 & no import of feed \\
\hline human needs for animal products & kton $\mathrm{Nyr}^{-1}$ & 77 & $=$ population $\times$ animal pdets consumptn & 77 & 47 & $=$ population $\times$ animal pdcts consumption \\
\hline local coverage in animal pdcts & $\%$ & 20 & $=$ local prod of animal pdcts/human needs & 100 & 100 & $=$ local prod of animal pdcts/human needs \\
\hline human needs for vegetal products & kton $\mathrm{Nyr}^{-1}$ & 41 & $=$ population $\times$ vegetal pdcts consumptn & 41 & 71 & $=$ population $\times$ vegetal pdcts consumption \\
\hline local coverage in vegetal pdcts & $\%$ & 1176 & $=$ local crop prod not used as feed/human needs & 446 & 357 & $=$ local crop prod not used as feed/human needs \\
\hline import(+)/export(-) animal pdcts & kton $\mathrm{N} \mathrm{yr}^{-1}$ & 62 & $=$ local animal pdets prod - local consumption & 0 & 0 & $=$ local animal pdets prod - local consumption \\
\hline $\begin{array}{l}\text { import }(+) / \text { export }(-) \text { vegetal pdcts } \\
\text { hydrosphere contamination }\end{array}$ & kton $\mathrm{Nyr}^{-1}$ & -445 & $=$ local vegetal food prod - local consumption & -143 & -182 & $=$ local vegetal food prod - local consumption \\
\hline $\mathrm{N}$ surplus on arable land & $\mathrm{kg} \mathrm{Nha}^{-1} \mathrm{yr}^{-1}$ & 99 & $=$ total fertilization - total crop prodctn & 70 & 20 & $=$ total fertilization - total cop production \\
\hline infiltration rate & $\mathrm{mm} \mathrm{yr}^{-1}$ & 300 & average for Seine watershed & 300 & 300 & average for Seine watershed \\
\hline sub-root $\mathrm{NO}_{3}$ conc & $\operatorname{mg~N} 1^{-1}$ & 33 & $=$ Nsurplus/infiltration rate & 23 & 7 & $=$ Nsurplus/infiltration rate \\
\hline
\end{tabular}



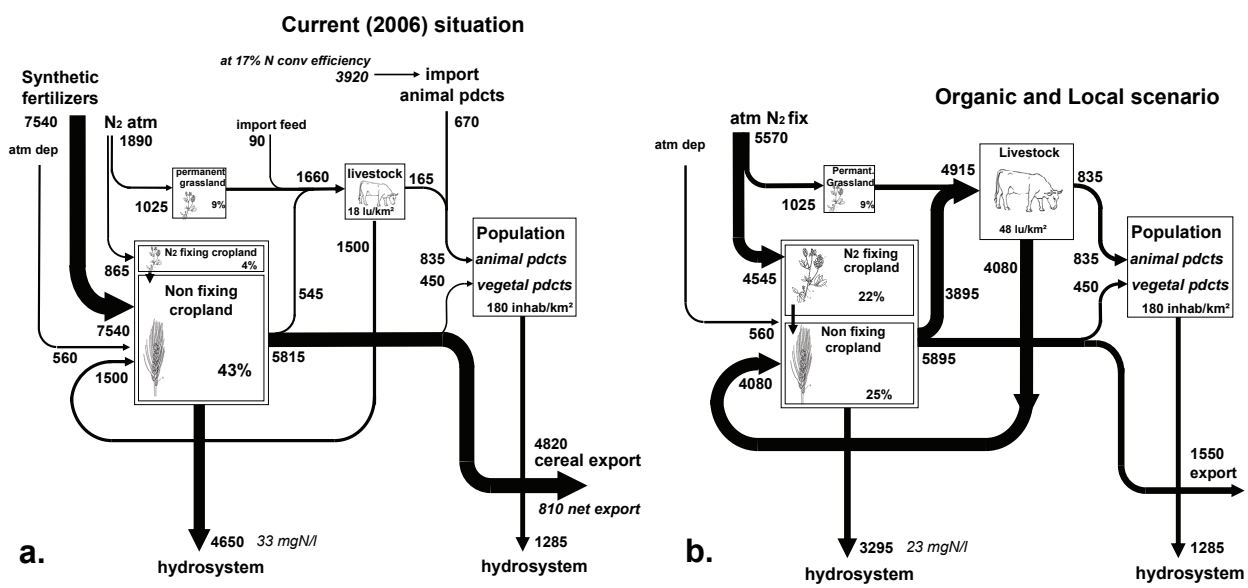

Seine watershed $\left(92000 \mathrm{~km}^{2}\right)$

Fluxes in $\mathrm{kgN} / \mathrm{km}^{2} / \mathrm{yr}$
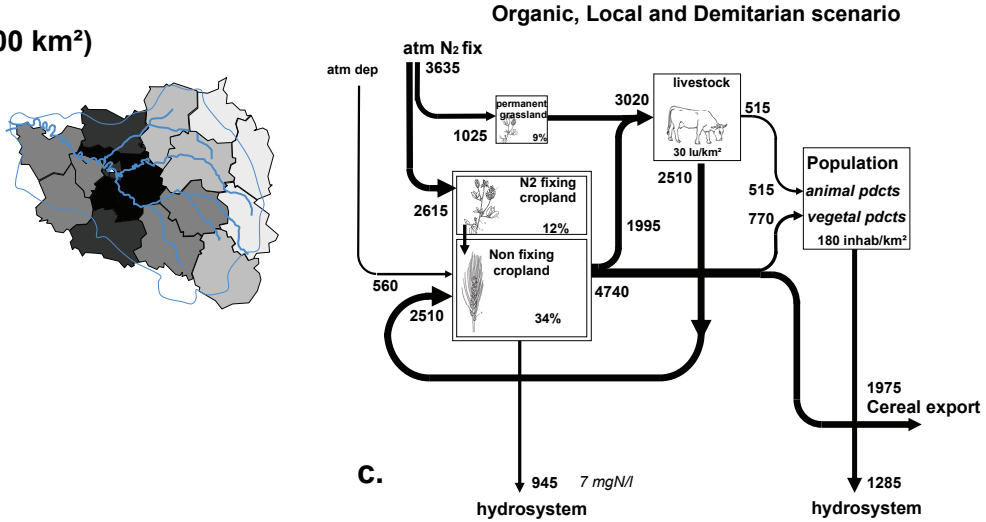

Fig. 3. Nitrogen fluxes in the agricultural system of the Seine watershed (fluxes expressed in $\mathrm{kg} \mathrm{N}$ per $\mathrm{km}^{2}$ of watershed area and per year). (a) Current situation (2006). (b) Organic and local scenario (OrgLoc). (c) Organic, local and demitarian scenario (OrgLocDem).

in the current situation, would still represent a sub-root water nitrate concentration double the drinking water standard.

\section{Changing the human diet}

The present human consumption of animal products in France accounts for $65 \%$ of the total protein intake. This rate is among the highest in the world (Fig. 4). The trend shown in Fig. 4 suggests that the share of animal product consumption in the human diet increases with the gross domestic product, as if meat and milk consumption were a sign of economic wealth. Yet the adverse public health effects of a high animal-protein diet are well documented both in terms of cardiovascular diseases (Lloyd-Williams et al., 2008) and colorectal cancer risks (Norat et al., 2005). A reduction of animal protein consumption in industrialised countries is also advocated for environmental reasons by NinE (2009) (The Barsac Declaration for a "demitarian" diet of 35-40\% animal proteins), and as a condition for world food security and equity in the Agrimonde scenario (Paillard et al., 2010).

We therefore decided to vary the share of animal products in the human diet and calculate the resulting effect on

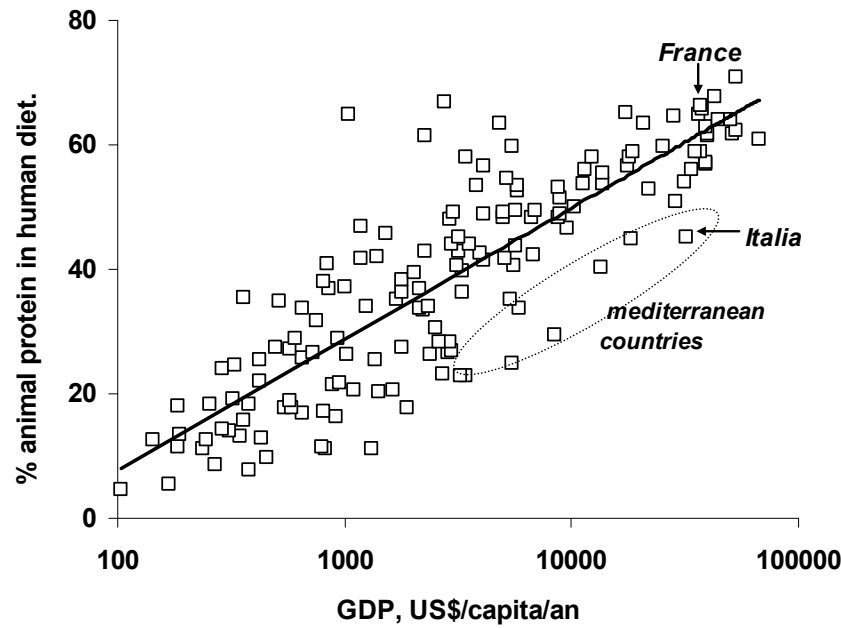

Fig. 4. Share of animal products in human total protein consumption of the world's countries in 2003, plotted against their GDP (sources: FAOstat, 2012). 

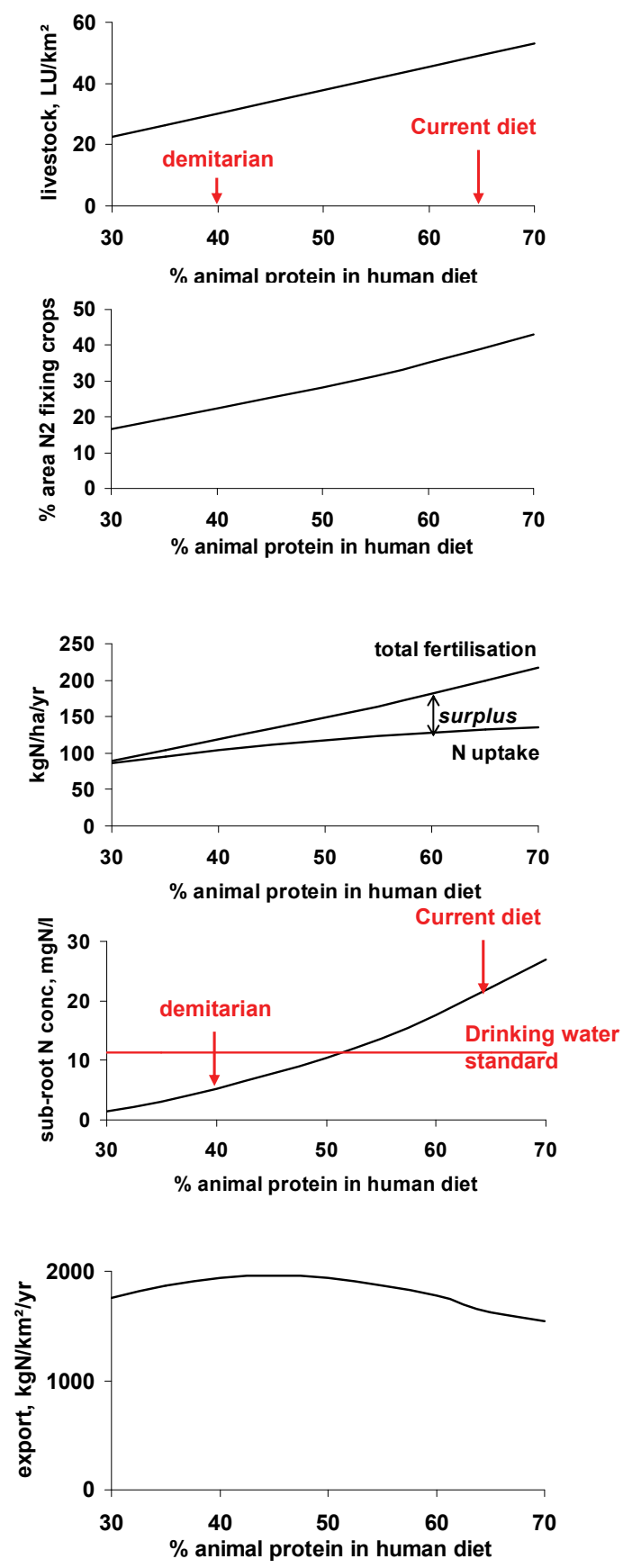

Fig. 5. Effect of reducing the proportion of animal-based protein in the human diet on the $\mathrm{N}$ fluxes through the agricultural system in an organic, local scenario of the Seine watershed.

the organic-localised scenario described above. Figure 5 shows the effect of reducing the proportion of animal protein in the total human diet of the Seine basin inhabitants from the present value of $65 \%$ to a "demitarian" diet of 35-40\% (NinE, 2009). Obviously, the area's self-sufficiency in terms of meat and milk production can be achieved in this scenario with lower livestock density, decreasing the total fertilisation

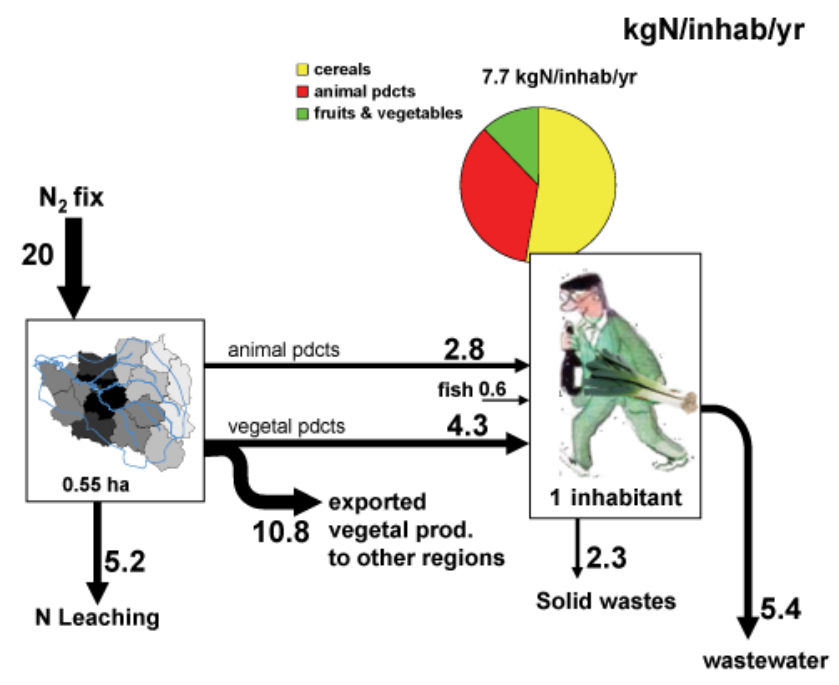

Fig. 6. Schematic representation of the nitrogen imprint of the food supply of one Paris inhabitant in the organic-localdemitarian scenario. The nitrogen fluxes involved are expressed in $\mathrm{kg} \mathrm{N}$ inhab $^{-1} \mathrm{yr}^{-1}$.

rate of arable land and the nitrogen surplus, without decreasing the area's cereal export capacity. With a demitarian diet, the Seine watershed should be able to feed its population, still export about $1950 \mathrm{~kg} \mathrm{~N} \mathrm{~km}^{-2} \mathrm{yr}^{-1}$ as cereal, and produce sub-root water meeting the best quality standards (Table 1 and Fig. 3).

The per capita imprint of the individual Parisian according to this organic-localised-demitarian (OrgLocDem) scenario is represented in Fig. 6. Compared with the current imprint as represented in Fig. 1, the area required to feed the individual Parisian in this scenario is similar to that required today, but can be mainly restricted to the surrounding traditional hinterland of Paris. The total reactive nitrogen injected into the process of food production is reduced to $20 \mathrm{~kg} \mathrm{~N}$ capita ${ }^{-1} \mathrm{yr}^{-1}$ compared to the $30 \mathrm{~kg} \mathrm{~N}_{\text {capita }}{ }^{-1} \mathrm{yr}^{-1}$ required in the current situation. The losses of reactive nitrogen by soil leaching are much lower, accounting for $40 \%$ of the losses at the final consumption stage, while these losses are $300 \%$ of this value in the current situation.

\section{Discussion and conclusion}

The impassioned controversy about localisation of food supply has been very well analysed by Cowell and Parkinson (2003). The defenders of the so-called Food-Miles movement put forward the benefits to be expected from localising agriculture in terms of both food security and environmental impact. They claim that regional self-sufficiency of food production and consumption is more likely to increase food security than a globalised food system. They also stress the negative environmental impacts of transporting 
foodstuffs over long distances. Finally they wish to reconnect people with food, neighbouring producers and seasonality, as well as to reduce the potential of environmental degradation and human exploitation by avoiding "out of sight, out of mind" effects produced by long-distance trade.

The opponents criticise the Food-Miles logic for its negation of productivity differentials between geographical locations, claiming that feeding a rapidly growing world population in a sustainable manner requires long-distance trade to ensure that food is produced most efficiently in the most suitable locations (Desrochers and Shimizu, 2008). Ballingal and Winchester (2008) go further by stating that local preference in food choices in Europe would lead to "starving the poor" by depriving Southern countries of important commercial income.

One particular aspect of the debate, the question of greenhouse gas $(\mathrm{GHG})$ emissions related to the transportation of foodstuffs, is probably the simplest to assess. All lines of evidence show that the benefits of localising food production are minor in that respect. For instance, Heyes and Smith (2008) showed that daily familial shopping trips between home and supermarket use as much energy as the overseas transport of the same amount of food, while Weber and Matthews (2008) demonstrated that transport is responsible for only a minor share of GHG emissions of the whole food production chain in the US and concluded that changes in agricultural practices or in the consumer diet composition have a much greater impact than localising production.

However, the debate has never included the question of drinking water supply even though drinking water production often competes with food production in the same land areas, particularly in the densely populated regions of Europe. This paper addresses the question of the compatibility of agriculture and water production in rural areas. For the Seine watershed, both the traditional feeding hinterland of Paris and its sole drinking water supply, we show that it is possible to conceive an agricultural system able to reconcile the dual function of rural areas, namely feeding the city and producing high-quality water.

The Paris basin area is emblematic because it is currently one of the most intensive cereals-producing areas in the world; some people even consider as its vocation to export grain to the rest of the world. This view should be tempered by the fact that most of these exports are currently intended for other European countries where a large part is used for animal feed. Nevertheless, what is striking in the OrgLoc and OrgLocDem scenarios is that they allow the Seine basin area to continue exporting a large share of its cereals production and in fact have a larger net export of proteins than in the current situation.

This purely biogeochemical approach is obviously restrictive and does not take into account the reluctance of either farmers, invested in their current technical, economic and social network, to shift their practices to organic farming, or consumers to change their eating habits so deeply embedded in both culture and commercial advertising influences. We simply delineate here the physical possibilities of a particular area.

In this respect also we are aware that the conclusions drawn herein can be quite easily caricatured. We know for instance that a number of foodstuffs consumed in Paris are imported from far away because they cannot be grown in the North of France. Our analysis of the nitrogen flows involved in the import of such products shows that these are minor (Billen et al., 2011), while they can account for a significant share of the monetary fluxes involved in feeding the city. This has always been the case, as Abad (2001) showed that already at the end of the 18th century, import to Paris of exotic and luxury agricultural goods (such as citrus fruits, tea, coffee, spices, etc.) already accounted for a significant value in the food "Great Market". Our approach is focused on the major biogeochemical fluxes associated with food production and consumption, because these are the most significant in terms of environmental impact, including water quality. There is no reason in this respect to advocate the complete cessation of exotic product imports. The localisation option explored in this paper concerns the general organisation of the agro-food system feeding Paris and the general balance of its inhabitants' diet, not the details of their occasional consumption of luxury products. In that sense, the suggestion that a shift to localising the food supply in Europe would "starve the poor" and "increase global inequality", as suggested by Ballingall and Winchester (2008), is irrelevant.

In a recent report (Westhoek et al., 2011), a scenario of $50 \%$ reduction of animal protein in the human diet in the EU has been explored at the global scale using the IMAGE model of the Netherlands Environmental Assessment Agency. The results are a strong decline in the import of protein-rich feed into Europe and an increase in cereal, meat and milk exports from Europe, so that the scenario would mainly have effects on land use and environmental quality outside the EU. Our purely biogeochemical approach differs from this one not only because we are not taking into account any economic mechanisms, but also because we first constrained the local agricultural system to self-sufficiency for feed and for meat and milk products. This additional constraint explains the strong local response of the system to decreasing the animal protein consumption observed in our scenario, in particular in terms of water quality. It therefore appears that localising as far as possible the major fluxes of food and feed supply at the regional scale is a pre-requisite to get full environmental benefits from a change to lower animal products in the human diet.

Acknowledgements. This study was conducted within the "Paris 2030" programme funded by the Ville de Paris, the Interdisciplinary Research Programme on City and Environment (PIRVE) directed by the French Ministry of Ecology, Sustainable Development, Transport and Housing (MEDDATT) and the CNRS, and the ANR "Ville Durable" Programme CONFLUENT. It is part of the activities coordinated by the FIRE (Fédération Ile-de-France de 
Recherche en l'Environnement) and the PIREN-Seine Programme. Discussions within the NinE ERC Research Network were also very useful in the development of the approach presented in this paper.

Edited by: J. W. Erisman

\section{References}

Abad, R.: Le Grand Marché: l'approvisionnement de Paris sous l'Ancien Régime, Fayard, Paris, 2002 (in French).

Agreste: Ministry of Agriculture, available at: www.agreste. agriculture.gouv.fr/, 2006.

Ballingall, J. and Winchester, N.: Food miles: Starving the poor?, University of Otago Economics Discussion Papers No. 0812, available at: www.business.otago.ac.nz/econ/research/ discussionpapers/DP_0812.pdf, 2008.

Barles, S.: Écologie territoriale, in: Dictionnaire de l'urbanisme et de l'aménagement, edited by: Merlin, P. and Choay, C., 3rd edn., PUF, Paris. 843 pp., 2010.

Billen, G., Garnier, J., Nemery, J., Sebilo, M., Sferratore, A., Benoit, P., Barles, S., Benoit, M.: A long term view of nutrient transfers through the Seine river continuum, Sci. Total Environ., 275, 80-97, 2007.

Billen, G., Barles, S., Garnier, J., Rouillard, J., and Benoit, P.: The Food-Print of Paris: Long term Reconstruction of the Nitrogen Flows imported to the City from its Rural Hinterland, Reg. Environ. Change, 9, 13-24, 2009.

Billen, G., Barles, S., Chatzimpiros, P., and Garnier, J.: Grain, meat and vegetables to feed Paris: where did and do they come from? Localising Paris food supply areas from the eighteenth to the twenty-first century, Reg. Environ. Change, online first: doi:10.1007/s10113-011-0244-7, 2011.

Charruadas, P.: The cradle of the city: the environmental imprint of Brussels and its hinterland in the High Middle Ages, Reg. Environ. Change, online first: doi:10.1007/s10113-011-0212-2, 2011.

Cowell, S. J. and Parkinson, S.: Localisation of UK food production: an analysis using land area and energy as indicators, Agr. Ecosyst. Environ., 94, 221-236, 2003.

Desrochers, P. and Shimizu, H.: Yes We Have No Bananas: A Critique of the Food Mile Perspective, Mercatus Policy Series, Policy Primer No. 8, available at: http://www.mercatus.org/uploadedFiles/Mercatus/Publications/ Yes\%20We\%20Have\%20No\%20Bananas_\%20A\%20Critique $\% 20$ of $\% 20$ the $\% 20$ Food $\% 20$ Mile $\% 20$ Perspective.pdf, last access: January 2012, 2008.

FAOstat: Statistics on production and international trade of food products, available at: http://faostat.fao.org/, 2012.

Galloway, J. N. and Cowling, E. B.: Reactive nitrogen and the world: 200 years of change, Ambio, 31, 64-71, 2002.

Gustavsson, J., Cederberg, C., Sonesson, U., van Otterdijk, R., and Meybeck, A.: Global food losses and food wastes. Extent, causes and prevention, FAO, Rome, 2011.

Heid, P.: Organic agriculture protects drinking water around $\mathrm{Mu}-$ nich, Germany, Ecology and Farming, 14, 24-34, 1997.

Heyes, J. A. and Smith, A.: Could Food Miles become a Non-Tariff Barrier?, SHS, Acta Hortic., 768, 431-36, 2008.
Keene, D.: Medieval London and its supply hinterlands, Reg. Environ. Change, online first: doi:10.1007/s10113-011-0243-8, 2011.

Lancelot, C., Thieu, V., Polard, A., Garnier, J., Billen, G., Hecq, W., and Gypens, N.: Ecological and economic effectiveness of nutrient reduction policies on coastal Phaeocystis colony blooms in the Southern North Sea: an integrated modeling approach, Sci. Total Environ., 409, 2179-2191, 2011.

Ledoux, E., Gomez, E., Monget, J. M., Viavatenne, C., Viennot, P., Ducharne, A., Benoit, M., Mignolet, C., Schott, C., and Mary, B.: Agriculture and groundwater contamination in the Seine basin. The STICS-MODCOU modelling chain, Sci. Total Environ., 409, 33-47, 2007.

Lloyd-Williams, F., Mwatsama, M., and Birt, C.: Estimating the cardiovascular mortality burden attributable to the Common Agricultural Policy on dietary saturated fats, B. World Health Organ., 86, 535-545, 2008.

NinE: The Barsac Declaration: Environmental Sustainability and the Demitarian Diet, available at: www.nine-esf.org/, 2009.

Norat, T., Bingham, S., and Ferrari, P.: Meat, fish and colorectal cancer risks: the European Prospective Investigation into Cancer and Nutrition, J. Natl. Cancer I., 97, 906-916, 2005.

Paillard, S., Treyer, S., and Dorin, B.: Agrimonde: Scénarios et défis pour nourrir le monde en 2050, Quae, Paris, 2010 (in French).

Paxton, A.: The Food Miles Report: the dangers of long distance food transport, Safe Alliance, London, 1994.

SitraM: Data base on commodity transport between French départements (French Ministry of Environment), www.statistiques.developpement-durable.gouv.fr/, 2006.

Smith, A., Watkiss, P., Tweddle, G., McKinnon, A., Browne, M., Hunt, A., Treleven, C., Nash, C., and Crossal, S.: The Validity of Food Miles as an Indicator of Sustainable Development, Final Report produced for DEFRA, ED50254, 103 pp., 2005.

Steele, C.: Hungry City: How food shapes our lives, Vintage books, London, 2008.

Stergiouli, M. L. and Hadjibiros, K.: The growing water imprint of Athens, the capital of Greece, The increasing flux of water resources from its hinterland throughout history, Reg. Environ. Change, online first: doi:10.1007/s10113-011-0260-7, 2012.

Sutton, M. A., Howarth, C. M., Erisman, J. W., Billen, G., Bleeker, A., Grennfelt, P., van Grinsven, H., and Grizzetti, B.: The European Nitrogen Assessment: Sources, Effect and Policy perspectives, Cambridge University Press, 612 pp., 2011.

Svirejeva-Hopkins, A. and Reis, S.: Nitrogen flows and fate in urban landscapes, in: The European Nitrogen Assessment: Sources, Effect and Policy perspectives, edited by: Sutton, M. A., Howard, C. M., Erisman, J. W., Billen, G., Bleecker, A., Grennfelt, P., van Grinsven, H., and Grizzetti, B., Chapter 12, 249-270, Cambridge University Press, 2011.

Swaney, D., Santoro, R. L., Howarth, R. W., Hong, B., and Donaghy, K. P.: Historical changes in the food and water supply systems of the New York metropolitan area, Reg. Environ. Change, online first: doi:10.1007/s10113-011-0266-1, 2012.

Tello, E. and Ostos, J. R.: Water consumption in Barcelona and its regional environmental imprint: a long-term history (17172008), Reg. Environ. Change, online first: doi:10.1007/s10113011-0223-z, 2011.

Thieu, V., Billen, G., and Garnier, J.: Nutrient transfer in three contrasting NW European watersheds: The Seine, 
Somme, and Scheldt Rivers. A comparative application of the Seneque/Riverstrahler model, Water Res., 43, 1740-1748, 2009.

Thieu, V., Garnier, J., and Billen, G.: Assessing the effect of nutrient mitigation measures in the watersheds of the Southern Bight of the North Sea, Sci. Total Environ., 408, 1245-1255, 2010.

Thieu, V., Billen, G., Garnier, J., and Benoît, M.: Nitrogen cycling in a hypothetical scenario of generalised organic agriculture in the Seine, Somme and Scheldt watersheds, Reg. Environ. Change, 11, 359-370, 2011.

Unifa: Livraisons d'engrais minéraux en France métropolitaine par département et par région. Union des Industries de la fertilisation, Paris, 2008 (in French).
Watts, D. C. H., Ilbery, B., and Maye, D.: Making reconnections in agro-food geography: Alternative systems of food provision, Prog. Hum. Geog., 29, 22-40, 2005.

Weber, C. and Matthews, H.: Food-Miles and the Relative Climate Impacts of Food Choices in the United States, Environ. Sci. Technol., 42, 3508-3513, 2008.

Westhoek, H., Rood, T., van de Berg, M., Janse, J., Nijdam, D., Reudink, M., and Stehfest, E.: The Protein Puzzle: the consumption and production of meat, dairy and fish in the European Union, The Hague: PBL Netherlands Environmental Assessment Agency, 2011 